\title{
New Insights into Valve Hemodynamics
}

\author{
Gil Marom, Ph.D. ${ }^{*}$ and Shmuel Einav, Ph.D. ${ }^{2}$ \\ ${ }^{\prime}$ School of Mechanical Engineering, Tel Aviv University, Tel Aviv Israel; and ${ }^{2}$ Department of Biomedical \\ Engineering, Tel Aviv University, Tel Aviv, Israel
}

\begin{abstract}
Heart valve diseases are common disorders with five million annual diagnoses being made in the United States alone. All heart valve disorders alter cardiac hemodynamic performance; therefore, treatments aim to restore normal flow. This paper reviews the state-of-the-art clinical and engineering advancements in heart valve treatments with a focus on hemodynamics. We review engineering studies and clinical literature on the experience with devices for aortic valve treatment, as well as the latest advancements in mitral valve treatments and the pulmonic and tricuspid valves on the right side of the heart. Upcoming innovations will potentially revolutionize treatment of heart valve disorders. These advancements, and more gradual enhancements in the procedural techniques and imaging modalities, could improve the quality of life of patients suffering from valvular disease who currently cannot be treated.
\end{abstract}

KEY WORDS: Aortic valve, heart valves, hemodynamics, mitral valve, pulmonary valve, tricuspid valves

\begin{abstract}
Abbreviations: AR, aortic regurgitation; ASME, American Society of Mechanical Engineers; BASILICA, bioprosthetic or native aortic scallop intentional laceration to prevent coronary artery obstruction; CAVD, calcific aortic valve disease; CAO, coronary artery obstruction; CE, Conformité Européenne; CFD, computational fluid dynamics; CT, computed tomography; FDA, Food and Drug Administration; ISO, International Organization for Standardization; MVR, mitral valve regurgitation; PVL, paravalvular leak; SAVR, surgical aortic valve replacement; TAVI, transcatheter aortic valve implantation; TMVR, transcatheter mitral valve replacement; US, United States; ViV, valve-in-valve.
\end{abstract}

Citation: Marom G, EInav S. New Insights into Valve Hemodynamics. Rambam Maimonides Med J $2020 ; 11$ (2):eoo14. Review. doi:10.5041/RMMJ.10400

Acknowledgements: Gil Marom acknowledges the partial support by grants from the Raymond and Beverly Sackler Fund for Convergence Research in Biomedical, Physical and Engineering Sciences and from the Nicholas and Elizabeth Slezak Super Centre for Cardiac Research and Biomedical Engineering at Tel Aviv University. Shmuel Einav acknowledges the partial support of the Drown Foundation and the H. Berman Fund.

Copyright: (c) 2020 Marom and Einav. This is an open-access article. All its content, except where otherwise noted, is distributed under the terms of the Creative Commons Attribution License (http://creativecommons.org/licenses/by/3.0), which permits unrestricted use, distribution, and reproduction in any medium, provided the original work is properly cited.

Conflict of interest: No potential conflict of interest relevant to this article was reported.

* To whom correspondence should be addressed. E-mail: maromgil@tau.ac.il 


\section{INTRODUCTION}

Heart valve diseases are common disorders with five million annual diagnoses in the United States alone. In general, these diseases can cause any of the four heart valves to malfunction, mostly as a result of stenosis or regurgitation, and they can only be treated by surgical or transcatheter interventions. Obviously, any heart valve disorder alters its hemodynamic performance; therefore, treatments are aimed at restoring blood flow to healthy conditions. This paper reviews the current valvular treatments from an engineering perspective, with a focus on hemodynamics. This review is inspired by Professor Rafael Beyar's contributions to cardiac treatments based on engineering principles, his aspiration for researchbased innovation, ${ }^{1,2}$ and his early research on computational simulations. This review will focus first on the aortic valve, which has been extensively studied and has the most substantial clinical experience with treatment devices. We will then review the latest advancement for the other valves of the heart. This review will conclude with a look at prosthetic valves and the hemodynamic standards to which they must comply.

\section{THE AORTIC VALVE}

There are two main acquired aortic valve disorders, both of which affect cardiac hemodynamics. Aortic root aneurysm is usually the cause of aortic insufficiency, where the valve leaflets cannot fully coapt. Aortic stenosis, on the other hand, is most commonly a result of calcific aortic valve disease (CAVD). Among the congenital disorders, bileaflet aortic valve is the most common. From a hemodynamic perspective, insufficiency is due to a regurgitating valve; hence, the preferred treatment is surgical valvesparing. This treatment provides physiologic hemodynamic conditions that have a much lower thrombogenic risk than prosthetic valves. ${ }^{3}$ However, the only treatment for the much more commonly occurring CAVD is valve replacement with a prosthetic valve. 4,5

Currently, two types of surgical prosthetic valves are available: mechanical and bioprosthetic (Figure 1, left panel). Mechanical valves are very durable and can be used in artificial hearts ${ }^{10}$; however, their main disadvantage is thrombus formation due to non-physiologic hemodynamics. Bioprosthetic valves, on the other hand, mimic the native valve function, thereby eliminating the long-term anticoagulation requirement, ${ }^{11}$ but they have limited durability com- pared with mechanical valves. Nevertheless, in recent years the American Heart Association, American College of Cardiology, European Society of Cardiology, and the European Association for CardioThoracic Surgery have updated their guidelines and lowered the recommended patient age for bioprosthetic valves. ${ }^{12}$ One rationale for this change is the extensive use of transcatheter aortic valve implantation (TAVI) and the ability to treat bioprosthetic valve failure with a valve-in-valve (ViV) procedure, ${ }^{13,14}$ thereby avoiding repeated open heart surgery. An additional option for rapid deployment of surgical bioprosthetic valves is the use of sutureless aortic valves ${ }^{15}$; however, these valves may increase the risk for complications that are usually associated with TAVI (described in the next section).

The flexible polymeric valve is a developing technology that may potentially combine the strengths of the mechanical and bioprosthetic valves, resulting in physiological hemodynamics with high durability. Moreover, this type of valve can be more cost-effective than a bioprosthetic valve since it will have a lower rejection rate during the manufacturing process. ${ }^{16,17}$ There is a long history of attempts to develop polymeric valves, which failed to receive regulatory approval. ${ }^{18}$ Nevertheless, several such devices are currently being developed and have demonstrated promising experimental results..$^{16,19-22}$ However, even if polymeric valves do achieve the hemodynamic capabilities of current bioprosthetic valves - with the durability of mechanical valvestheir inability to grow makes them problematic for pediatric use. Tissue-engineered heart valves may, potentially, be able to adjust to both tissue growth and remodeling, therefore ensuring prolonged durability. ${ }^{23}$ While tissue-engineered heart valves have been tested in limited clinical studies since the beginning of the $2000 \mathrm{~s},{ }^{23}$ there is still a need for basic understanding on the tissue process, as well as the outcomes and mechanical function, before this technology can undergo regulatory approval. ${ }^{24}$ These two developing technologies are presented in the right panel of Figure 1.

\section{TRANSCATHETER AORTIC VALVE IMPLANTATION}

Transcatheter aortic valve implantation is an alternative to surgical aortic valve replacement (SAVR). A stented bioprosthetic valve is delivered via catheterization and deployed inside the stenotic native valve. ${ }^{25,26}$ In the latest generation of devices, the 


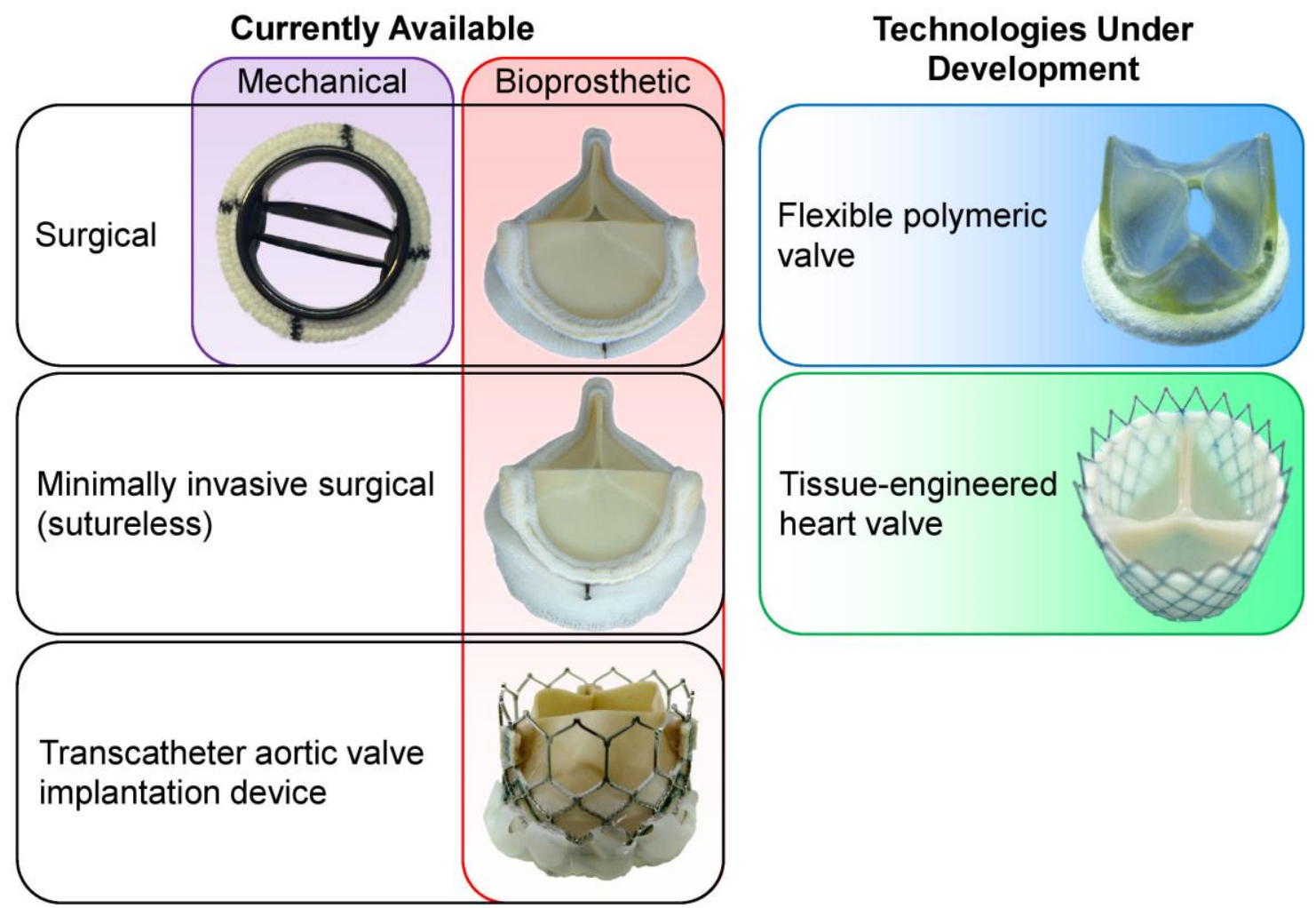

Figure 1. Available (Left) and Under Development (Right) Prosthetic Aortic Valve Technologies. Photographs adapted and modified from Figure 5 of Spühler et al. ${ }^{6}$ [CC BY 4.0], Figure 1 of Capelli et al. ${ }^{7}$ [CC BY $\underline{4.0}$ ], Figure 6 of Ghanbari et al. ${ }^{8}$ [CC BY-NC 3.0], and Figure 1 of Sanders et al. ${ }^{9}$ [CC BY 4.0].

only US Food and Drug Administration (FDA)approved TAVI devices are the balloon-expandable Sapien 3 Ultra (Edwards Lifesciences Corp., Irvine, CA, USA), the self-expandable Evolut Pro (Medtronic, Minneapolis, MN, USA), and the self-expandable and mechanically locked Lotus Edge (Boston Scientific, Marlborough, MA, USA). ${ }^{27}$ In addition to these three devices, numerous other TAVI devices (including the Portico from Abbott, the Acurate Neo from Boston Scientific, and JenaValve's device) have received Conformité Européenne (CE) marks ${ }^{16}$; however, most of them have been discontinued. While each of the various CE-marked devices has its own advantages, these advantages are usually related to aspects other than valve hemodynamics. Although TAVI was originally approved for only high-risk surgical patients, it is now approved for low-risk surgical patients. ${ }^{28}$ This recent change could increase the annual number of TAVI procedures from 180,000 to 270,000 in Europe and North America. ${ }^{29}$ In addition to the classical use of TAVI in CAVD, both self-expanding and balloonexpandable TAVI devices are FDA-approved for ViV implantation. ${ }^{30}$ However, the suture ring of the SAVR makes it narrower than the native root, and inserting a TAVI reduces the orifice area of the valve even more, thereby harming hemodynamic performance. ${ }^{31}$ Additionally, some of the TAVI complications are more common in ViV (discussed in the next section). Transcatheter aortic valve implantation is also being used in bileaflet aortic valve patients at high surgical risk, although such use has not yet been approved for this population. ${ }^{32}$ The risk of various hemodynamic complications is also higher than in CAVD patients, due to the non-circular anatomical shape of the aortic valve in these patients.

\section{Hemodynamic Complications}

The new-generation TAVI devices demonstrates a vast decrease in complications; however, the existence of some adverse outcomes remains a concern due to the shift toward use in lower-risk patients. ${ }^{31}$ Some of these complications include conduction abnormalities (necessitating permanent pacemaker implantation), coronary artery obstruction (CAO), paravalvular leak (PVL), and valve thrombosis. ${ }^{31}$ The 
two last-mentioned are direct hemodynamic complications.

\section{Paravalvular leak}

Paravalvular leak is a leakage through the gaps between the implanted stent of TAVI devices and the native valve (Figure 2). This adverse hemodynamic outcome has been significantly minimized in the latest-generation devices, from a prevalence in patients of $25 \%$ to $5 \% .{ }^{16}$ This reduction was achieved by adding an outer skirt or cuff that covers the ventricular portion of the stent. In the original Sapien 3 valve, the outer skirt included openings that created pockets that could fill with blood, thereby sealing the paravalvular gaps. ${ }^{16}$ This design was later refined in the Sapien 3 Ultra valve by increasing the outer skirt height, closing the pockets, and adding texture to the polyethylene terephthalate fabric. While the latest self-expandable devices also have an outer skirt, they can seal the gaps with an optimized anatomical fitting, specifically by having a larger stent diameter on the ventricular side than in the valve region. In addition to design improvements in the latest devices, if aortic regurgitation (AR) is found immediately following implantation, PVL is minimized by post-dilation with ballooning. These advances significantly reduced the incidence of AR post-TAVI; however, moderate-to-severe AR is still much more frequent compared to SAVR. 35 Since PVL is a very patient-specific complication, from an engineering point of view, it is more useful to evaluate it with computational fluid dynamics (CFD) than with bench experiments. ${ }^{6}$ In CFD, the basic equa- tions that describe the flow of a fluid are solved by computational software. Therefore, CFD enables virtual replication of procedural options that cannot be tested in vitro for specific patients. Several studies have used CFD ${ }^{37-41}$ and fluid-structure interaction, ${ }^{42}$ where the fluid dynamics equations are coupled with solid mechanics models, to estimate PVL. This is also one of the features of a commercial service for pre-procedural planning based on patient-specific scans, as described below (Patient-specific Preprocedural Planning Based on Numerical Models).

\section{Thrombogenicity}

Hemodynamics is one of the main contributing factors for thrombosis.43,44 Exposure of platelets to elevated flow stresses and platelet adhesion in stagnant flow regions are considered the two main mechanical causes of thrombogenicity. ${ }^{45,46}$ In heart valves, these two factors, along with non-hemodynamic factors like hemocompatibility, can cause leaflet thrombosis or thromboemboli. In mechanical valves, the main concern is thrombus formation resulting from disturbed flow and elevated shear stress in the regurgitant flow through the narrow gaps. While it is true that the narrow gaps in PVL around TAVI can also cause this type of thrombus formation, 40,47 obviously the leakage itself is usually a bigger concern than the thrombosis and constitutes the rationale behind performing post-TAVI dilation. On the other hand, blood flow stagnation in the valvular region is the suggested cause of leaflet thrombosis in TAVI, both in clinical studies 48 and based on in vitro particle image velocimetry (PIV) measurements of the

\section{Schematic Description}

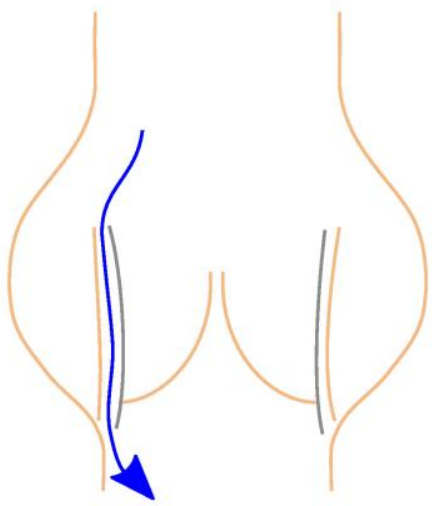

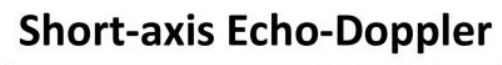

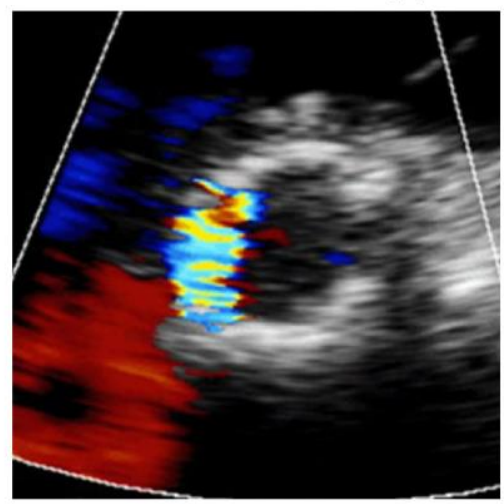

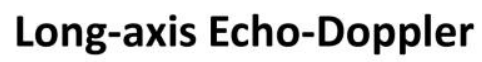

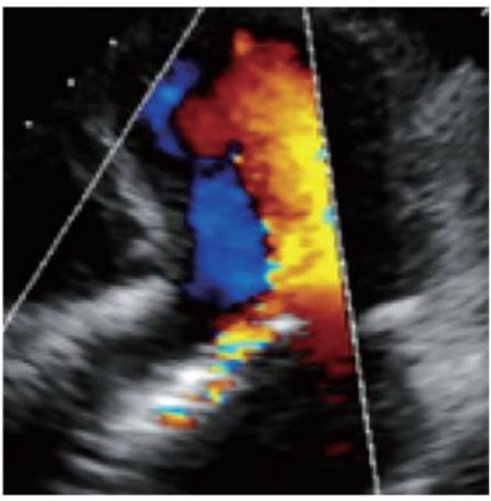

Figure 2. Paravalvular Leak Post-Transcatheter Aortic Valve Implantation (TAVI).

Schematic description of paravalvular leak with examples of how it is seen in echo-Doppler images (adapted from Figure 3 of Di Martino et al. ${ }^{33}$ [CC BY 4.0] and Figure 14 of Sordelli et al. ${ }^{34}$ [CC BY-NC-SA]). 
flow velocity vector field (Figure 3 ). ${ }^{50,51}$ Specifically, leaflet thrombosis is the assumed reason for reduced leaflet motion, $5^{2}$ as a result of hypoattenuated leaflet thickening. ${ }^{53}$ The prevalence of leaflet thrombosis remains unknown since cases that have not been diagnosed clinically have been discovered in pathological valve studies, $4^{8}$ but frequencies of $16 \%$ in Sapien 3, 8\% in Evolut, and 14\% in Lotus TAVI devices as compared with $4 \%$ in SAVR patients have been suggested..$^{2}$ Additionally, the occurrence of leaflet thrombosis post-ViV placement was reported to be six times the occurrence of leaflet thrombosis post-TAVI in native valve. 54

Several attempts have been made to study the hemodynamic causes of hypoattenuated leaflet thickening by engineering methods, both experimental and numerical. Experimental studies compared the native valve to TAVI, ${ }^{\circ}$ surgical valve to $\mathrm{ViV}^{51}$ with idealized geometry, or surgical valve to ViV with commercial valves. 55 Numerical studies that compared surgical valve to $\mathrm{ViV}^{56}{ }^{-5} 8$ by $\mathrm{CFD}$ with prescribed leaflets motion also employed idealized geometry that were experimentally measured. ${ }^{57,58}$ All these studies demonstrated that valve confinement, where the TAVI valve is surrounded by the previous leaflets of the native or the degenerated SAVR valve, can increase the blood residence time near the leaflets. Therefore, supra-annular implantation, like in Evolut (where the TAVI valve is only partially confined), is expected to have a lower thrombogenic risk than a fully confined valve, such as the intra-annularly implanted Sapien..$^{8}$ A recently proposed method to address CAO is to lacerate the leaflets of the bio-

\section{Schematic Description Leaflet Thickening as Result of Thrombosis}
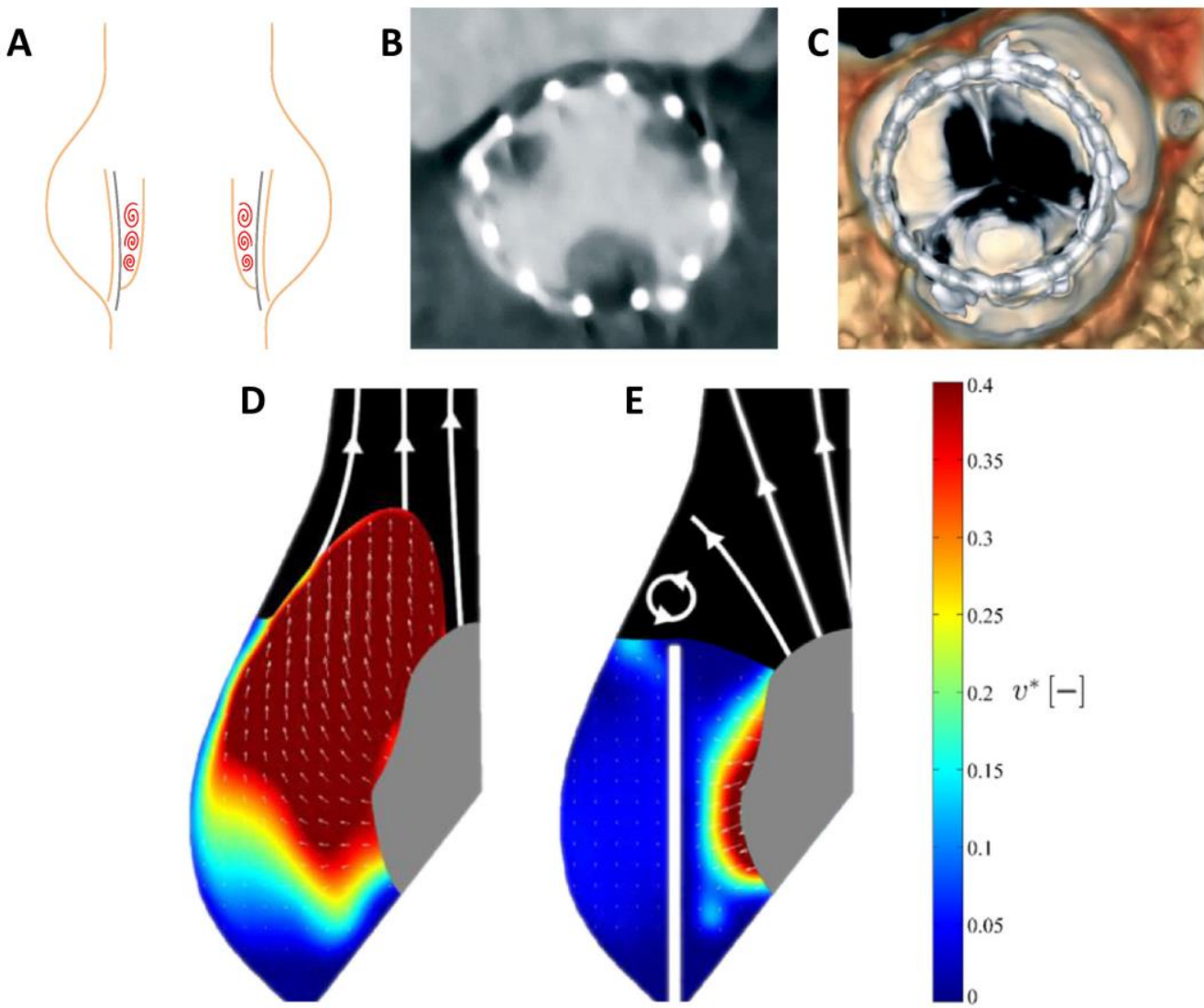

Figure 3. Flow Stasis Post-Transcatheter Aortic Valve Implantation (TAVI) and Leaflet Thickening That Indicates Thrombosis Location.

Schematic description of potential stasis (A). Leaflet thickening as seen in both CT (B) and volume-rendered 4D-CT scans (C). Blood velocity magnitude as measured from in vitro experiment that represents native aortic valve (D) and post-TAVI (E). Blue shades represent stagnation (low velocities). CT scans and experimental results are adapted from Figure 2 of Rosseel et al. ${ }^{49}$ [CC BY 4.0] and Figure 5 of Ducci et al. ${ }^{50}$ [CC BY 4.0]. 
prosthetic valve by a technique known as BASILICA (bioprosthetic or native aortic scallop intentional laceration to prevent coronary artery obstruction) 59 (see below, Hemodynamics of structural complications). In addition to the original intention of this technique, engineering studies suggest that the laceration can allow better washout and reduce the flow stagnation in the valvular region, thus leading to lower thrombogenic risk. ${ }^{60,61}$

\section{Hemodynamics of structural complications}

In addition to these two direct hemodynamic complications, the other TAVI complications also affect blood flow. Coronary artery obstruction obviously has a major effect on coronary hemodynamics. It is more common in ViV cases than in classical TAVI, and is related the to the surgical valve design, with a complication rate of up to $5.3 \%$ for externally mounted surgical valves. ${ }^{62,63}$ Patients suspected of being at risk for $\mathrm{CAO}$, based on pre-procedural imaging, should be protected pre-emptively by "chimney" stenting. ${ }^{64}$ An alternative to chimney stenting is the BASILICA technique 59 where the laceration directly prevents obstruction. While CAO risk is currently evaluated based only on the anatomic location of the coronary ostia, numerical models can help to quantitatively assess flow dynamics. 65,66 The circularity and size of the valve orifice can be highly dependent on patient anatomy, especially with self-expandable TAVI devices. Clearly, it is undesirable to have a non-circular valve, and this phenomenon has been generally been addressed by the supra-annular design of the TAVI device. ${ }^{16}$ Finally, valve embolization (migration) exemplifies structural complications due to hemodynamics. While it is relatively rare (occurrence as low as $0.5 \%)^{67}$ and considered a consequence of insufficient anchoring, valve embolization is a direct result of the diastolic blood pressure pushing the valve into the ventricle. Recently, we suggested that BASILICA can weaken anchorage forces, although our study did not indicate that it was weakened enough to cause migration. ${ }^{68}$ Stronger anchoring forces, for example by over-inflating the balloon-expandable device, can obviously help prevent migration. Nevertheless, these approaches can cause additional nonhemodynamic complications such as conduction abnormalities (necessitating permanent pacemaker implantation) or even aortic root rupture.

\section{Patient-specific Pre-procedural Planning} Based on Numerical Models

In recent years, several numerical models have been approved for patient-specific procedural planning in various medical treatments. ${ }^{69}$ The FEops HEARTguide (FEops nv, Gent, Belgium) is a CE-marked service for making pre-interventional TAVI device size and position recommendations based on patientspecific numerical models. The recommendations are based on both finite element analysis of the implantation $^{70}$ and CFD analysis of the postprocedural PVL. 37 To utilize this service, clinicians send routine computed tomography (CT) scans of the patient to the company. The company then reconstructs the cardiac anatomy, generates and runs the finite element analysis and CFD simulations, and provides a report on the results of several scenarios within two working days. Since the first presentation of this tool, numerous studies have demonstrated its clinical usage including for implantation in bicuspid aortic valves, ${ }^{71-73}$ and the use of TAVI in the mitral location with native calcified valves 74,75 and inside a failed bioprosthetic valve. ${ }^{7}$ Use of the FEops HEARTguide has also been expanded to additional TAVI devices, 77 device optimization, 78 and also for procedural recommendations based on additional possible complications, such as conduction abnormalities.79 From a hemodynamic perspective, the most important capability of this tool is obviously calculation of PVL (Figure 4), which demonstrated good predictions in a clinical study of 60 patients. 37 On the other hand, in a study that used the FEops HEARTguide to compare coronary flow with several TAVI orientations, ${ }^{8}$ there was no difference between the flow results in the various cases.

\section{THE MITRAL VALVE}

Mitral valve regurgitation (MVR) is a leakage due to improper closure of the valve. It is the most common valvular heart disease with a prevalence of approximately $1.7 \%$ in the adult population. ${ }^{81}$ Due to its increased prevalence with age and the growing aging population, the number of cases in the year 2030 is expected to be almost double that of the year 2000. ${ }^{82}$ Mitral valve regurgitation is caused by either a valve prolapse (primary MVR, due to a degenerative abnormality of the leaflets, chordae tendineae, papillary muscles, or the mitral annulus) 


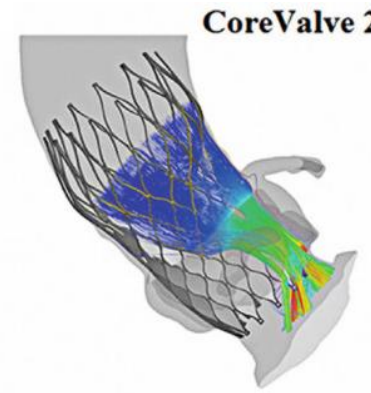

High implant PVL $47 \mathrm{ml} / \mathrm{s}$

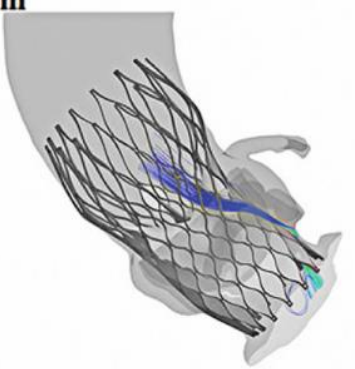

Low implant

PVL $6 \mathrm{ml} / \mathrm{s}$

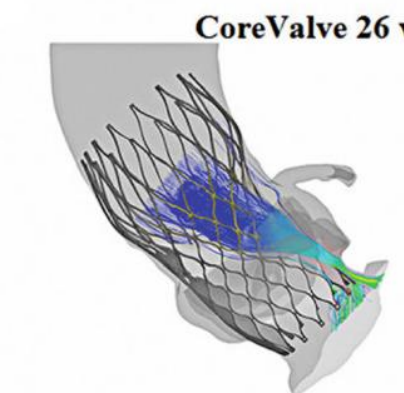

26

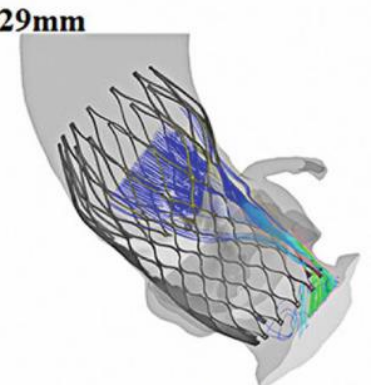

29 PVL $14 \mathrm{ml} / \mathrm{s}$

PVL $19 \mathrm{ml} / \mathrm{s}$

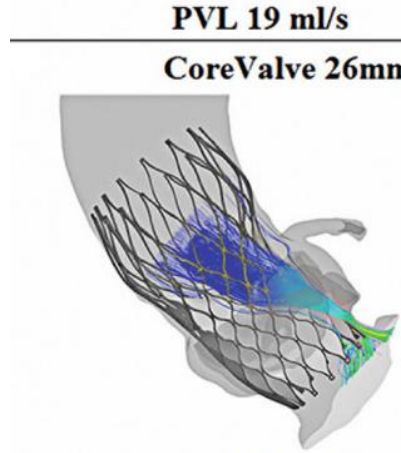

CoreValve 26 PVL $19 \mathrm{ml} / \mathrm{s}$

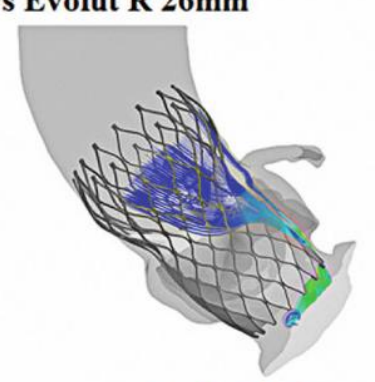

Evolut R 26 PVL $9 \mathrm{ml} / \mathrm{s}$

Figure 4. Patient-specific Pre-procedural Paravalvular Leak Calculations.

Examples of paravalvular leak calculations using the FEops HEARTguide. This platform can help minimize leakage by pre-selecting the optimal transcatheter aortic valve device and implantation location. Adapted from Figure 5 of $\mathrm{El}$ Faquir et al. ${ }^{80}$ [CC BY 4.0].

or a left ventricular dysfunction (secondary or functional MVR). 83 Current treatments include mostly surgical valve repair or replacement. 84 Valve replacement involves replacing the native valve with a prosthetic one. Obviously, implantation orientation significantly influences the flow pattern, especially with mechanical valves, but it is less clear what the optimal orientation is. ${ }^{85}$ In a valve repair, the native valve remains in place, and the leaflets, chordae, and papillary muscle are manipulated to restore normal valve behavior with a stabilized annulus while pre- serving the valve's orifice size and left ventricular function. ${ }^{86,87}$ Repair techniques are based on annuloplasty, resection, addition of artificial chordae, or a combination thereof.88,89 Annuloplasty, with either rigid or flexible rings or bands, is necessary in most repairs. ${ }^{\circ 0}$ Valve repair is recommended for patients with primary MVR ${ }^{\circ}$ since the repair has a low mortality rate ${ }^{91}$ and it improves ventricular function with no need for anticoagulation. However, there remains a risk of residual MVR and concerns regarding mitral valve repair durability. ${ }^{92}$ 
Unfortunately, the majority of severe MVR patients are not treated due to the high surgical risk, leading to considerable morbidity and mortality. $.93,94$ As a consequence, these patients can only be treated percutaneously. There is one such device that has been approved for MVR by the FDA, the MitraClip (Abbott Laboratories, Abbott Park, Illinois, USA). This transcatheter procedure involves the implantation of a clip that grasps both the anterior and the posterior leaflets of the mitral valve, mimicking surgical edge-to-edge valve repair that is done via open heart surgery. 95 However, the procedural results are often suboptimal even in patients who meet the inclusion criteria, i.e. severely symptomatic secondary MVR patients. ${ }^{66}$ The Pascal system (Edwards Lifesciences Corporation, Irvine, CA), which is still in clinical trials, is another edge-to-edge valve repair device that aims to tackle some of these limitations by including wider paddles and a central spacer. 97 Other percutaneous CE-marked interventions are based on direct (Mitralign System, from Mitralign, Inc., Tewksbury, MA, USA; Cardioband, from Edwards Lifesciences) and indirect (Carillon System, from Cardiac Dimensions, Inc., Kirkland, WA, USA) mitral annuloplasty. 95,98

Transcatheter mitral valve replacement (TMVR) is a potential alternative to surgical treatment for a wide range of pathologies that cannot currently be treated percutaneously.95 However, TMVR has unique challenges, such as the size and shape of the valve, lack of calcification deposits for anchorage, high hemodynamic pressures, and complex subvalvular apparatus. These challenges led to a limited clinical experience with such devices. 93 A significant effort is being made to develop TMVR devices, with more than 10 currently at various stages of development.99-101 These TMVR devices have several mechanisms for anchorage and sufficient sealing around the device. Unlike TAVI, the main anchoring challenge focuses on not applying strong radial forces, which can obstruct and damage the aortic valve. ${ }^{101}$ Suggested TMVR anchoring mechanisms include counteracting axial forces by using ventricular tethers, native valve anchors, atrial and ventricular flanges, sub-annular hooks, atrial cages, and implantation of a docking system. From a hemodynamic perspective, all these anchoring mechanisms contribute to some flow disturbances. Nevertheless, flow through the valve itself should be similar to the flow through any other type of bioprosthetic valve. Another possible procedural complication with a direct hemodynamic effect is left ventricular outflow tract obstruction. For these cases, laceration of the anterior mitral leaflet to prevent outflow obstruction $^{102,103}$ was suggested, a technique similar to using BASILICA in a TAVI.

Several studies used engineering methods to experimentally study the hemodynamics of the mitral valve, including MVR before and after treatment. ${ }^{104-106}$ Numerical methods have also been employed to model healthy and diseased mitral valves, before and after surgery. ${ }^{107-112}$ Both mitral annuloplasty ${ }^{113-118}$ and edge-to-edge procedures ${ }^{119-}$ ${ }^{121}$ have been modeled with finite element analysis to evaluate their effect on tissue stress, tension in the chordae tendineae, and hemodynamics. Most numerical models of percutaneous MVR treatments focused on evaluating the commercially available MitraClip. ${ }^{105,119-122}$ Sturla et al. ${ }^{105}$ studied the effect of MitraClip implantation with both in vitro experiments and numerical models. While hemodynamics was not modeled numerically, it was measured experimentally. Therefore, this study was able to find a correlation between the "dry" experimental results and hemodynamics. Kamakoti et al. ${ }^{122}$ presented numerical simulations of fluid structure interaction in the mitral valve post-MitraClip implantation (Figure 5). Their main focus was regurgitation reduction using the MitraClip, and their results indicated the importance of the grasping location. While no study presented numerical simulations of TMVR devices, both Karady et al.74 and Serban et al.75 described use of the FEops HEARTguide to model TAVI devices (the Lotus valve from Boston Scientific, and the Sapien 3 from Edwards Lifesciences, respectively) in the mitral location. In these cases, patients suffered from severe MVR and mitral valve stenosis with significant mitral valve annulus calcification. This specific pathology enabled the use of TAVI devices rather than a dedicated TMVR device.

\section{THE PULMONARY AND TRICUSPID VALVES}

The pulmonary and tricuspid valves are located in the outlet and inlet of the right ventricle. Obviously, the right ventricle has the same stroke volume as the left ventricle, but by exerting only one-fourth of the work and approximately one-sixth of the pressure. ${ }^{123}$ While the vast majority of valvular heart diseases occur in the aortic and mitral valves, there is still a large unmet need for surgical and percutaneous treatments for patients with pulmonary and tricus- 

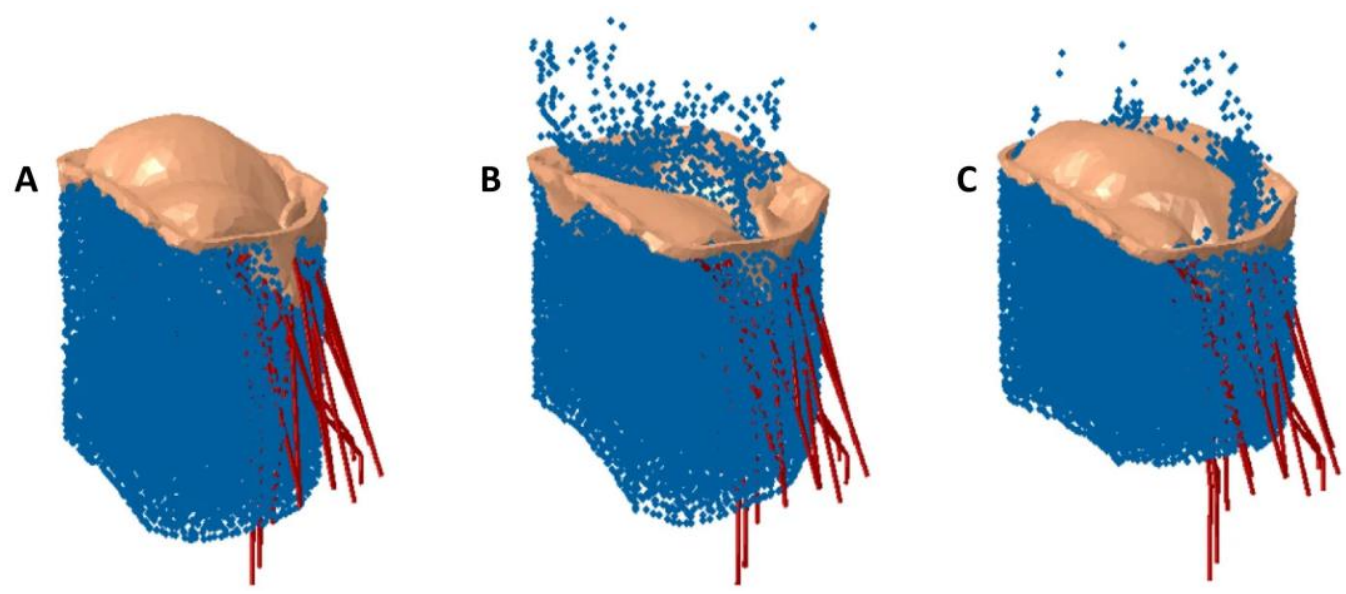

Figure 5. Comparison of Calculated Leakage in the Mitral Valve.

A: Healthy mitral valve. B: Regurgitating mitral valve. C: Regurgitating mitral valve post-MitraClip shows significant leakage reduction. Adapted from Figure 5 of Kamakoti et al. ${ }^{122}$ [CC BY 4.0].

pid valve disorders. Treatments for these disorders need to properly function under the low hemodynamic pressure gradients of the right heart.

The two types of pulmonic disorders are stenosis, a relatively common congenital defect, ${ }^{81}$ and regurgitation, attributed to a variety of causes. While the gold standard treatment for pulmonic valve stenosis is balloon valvuloplasty, this treatment has longterm complications of regurgitation and restenosis. ${ }^{124}$ Severe regurgitation is treated by valve replacement, usually performed percutaneously. There are two FDA-approved devices for transcatheter pulmonary valve implantation: the Melody ${ }^{\mathrm{TM}}$ (Medtronic, Dublin, Ireland) and the Sapien XT (Edwards Lifesciences Corporation, Irvine, California, USA). Both devices are approved for patients with prosthetic valve regurgitation, ${ }^{125}$ while the Melody is also being implanted off-label in native valves. ${ }^{126,127}$ While transcatheter pulmonary valve implantation was found to have high procedural success, ${ }^{125}$ there are still concerns regarding complications. While most of the complications are structural, damage to the tricuspid valve was recently reported as a cause for tricuspid valve regurgitation..$^{128}$ Only a few engineering hemodynamics studies have focused on the pulmonary valve. Suzuki et al. ${ }^{129}$ presented an in vitro experimental study of the hemodynamics in a polymeric pediatric pulmonary valve prosthesis. Capelli et al. ${ }^{130}$ used numerical models of patient-specific anatomies to predict the clinical outcomes of Melody valve implantation and found good agreement between their results and clinical fluid-dynamic parameters. Recently, Li et al. ${ }^{131}$ presented fluid-structure interaction models of pulmonary valve stenosis as a result of congenital bicuspid pulmonary valve. While the flow dynamics was modeled, most of their results focused on the geometrical differences between tricuspid and bicuspid configurations, and the only hemodynamically relevant finding was related to the geometric orifice area.

Similar to the mitral valve, tricuspid regurgitation can be treated by surgery, usually to reduce the annular dimensions, but it is recommended only in severe cases that do not have high surgical risk. ${ }^{96}$ Percutaneous treatment of tricuspid regurgitation is highly desirable because most patients with moderate-to-severe regurgitation cannot be treated surgically. ${ }^{132}$ Several percutaneous devices and techniques have been suggested for tricuspid treatments, some of which are based on adaptation of mitral valve repair. Several devices for transcatheter tricuspid annuloplasty are in development, ${ }^{132}$ including the Mitralign System, ${ }^{133}$ the 4 Tech TriCinch $^{\mathrm{TM}}$ (4Tech Cardio Ireland, Ltd, Galway, Ireland), ${ }^{134}$ and the transatrial intrapericardial tricuspid annuloplasty concept. ${ }^{135}$ Additionally, edge-to-edge repair of the tricuspid valve with the MitraClip device has also been suggested. ${ }^{136}$ Of these, engineering tools were used to evaluate only the post-procedural hemodynamics after MitraClip implantation. Vismara et al. ${ }^{137}$ presented an experimental in vitro study that tested several procedural options for transcatheter edge-to-edge repair and found it to be a viable treatment for tricuspid valve regurgitation. They compared implantation of one or two clips and 
considered several combinations of clipped leaflets and clipping locations. They found that grasping should involve the septal leaflet to improve both cardiac output and pressure recovery, and that the clip should be in the middle rather than a commissural position. While the two-clip procedure was effective when grasping the septal and anterior leaflets, there was no significant improvement compared with the single clip procedure. Recently, Dabiri et al. ${ }^{138}$ used numerical models to perform a similar study on the effect of MitraClip positioning. This study only considered the grasping of the septal and posterior leaflets with three grasping locations and the use of two clips. They concluded, similarly to Vismara et al.,137 that a single clip placement in the middle produced the best outcomes and that there was no further improvement by the second clip.

\section{HEMODYNAMIC STANDARDS FOR TESTING PROSTHETIC VALVES}

Regulatory approval of a new prosthetic valve requires demonstration of adequate hemodynamic performance. The current standards for TAVI devices (International Organization for Standardization [ISO] 5840-3) and surgical valves (ISO 5840-2) describe the experimental methods and minimum requirements for hemodynamic performance. For example, the effective orifice area of TAVI valves is required to be larger than that of comparable size SAVR valves. This requirement is a direct consequence of the thinner stent relative to the surgical suture ring, which increases the opening area of TAVI. In addition to the ISO standard, there is a trend toward in vitro experiments with patientspecific anatomies. ${ }^{20,139-148}$ This trend paves the way to more physiologic results, which until now could only be numerically simulated. ${ }^{16,144}$ Therefore, patient-specific experiments can also provide a better platform for validation of numerical models. This is specifically important with the current advances in pre-procedural planning (see Patient-specific Preprocedural Planning Based on Numerical Models, above) and the increased demand by regulatory agencies to rely on computational modeling for device approval. ${ }^{149}$ The main reason for this requirement is that numerical models can still capture hemodynamic details that cannot be measured by any other means, ${ }^{150}$ such as the $3 \mathrm{D}$ velocity vector field or the spatial distribution of shear stress. In an attempt to standardize the numerical modeling methodologies and their credibility, the FDA became involved with the American Society of Mechanical
Engineers (ASME) Committee for the new verification and validation standard for computational modeling of medical devices (ASME V\&V 40).

\section{SUMMARY}

This paper reviewed state-of-the-art clinical and engineering advancement in heart valve treatments, with a focus on hemodynamics. Since the beginning of the twenty-first century, the field has been rapidly changing with the introduction of transcatheter heart valve implantation and repair. This review has looked at the treatment of heart valve disorders and several advancements currently under development or with limited use, which, in the near future, will potentially revolutionize their treatment. Examples of some of these devices include flexible polymeric valves, patient-specific pre-procedural planning based on numerical models, and the expansion of transcatheter valve implantation to the mitral, pulmonary, and tricuspid valves. These advancements, and more gradual enhancements in procedural techniques and imaging modalities, could improve the quality of life of patients suffering from valvular disease who cannot, currently, be treated.

\section{REFERENCES}

1. Beyar R. High technology in medicine: lessons from cardiovascular innovations and future perspective. Rambam Maimonides Med J 2013;4:eooo9. Crossref

2. Beyar R. The long and winding road to innovation. Rambam Maimonides Med J 2015;6:eo030. Crossref

3. De Paulis R, De Matteis GM, Nardi P, Scaffa R, Buratta MM, Chiariello L. Opening and closing characteristics of the aortic valve after valve-sparing procedures using a new aortic root conduit. Ann Thorac Surg 2001;72:487-94. Crossref

4. Marom G. Numerical methods for fluid-structure interaction models of aortic valves. Arch Comput Methods Eng 2014;22:595-620. $\underline{\text { Crossref }}$

5. Halevi R, Hamdan A, Marom G, et al. Fluid-structure interaction modeling of calcific aortic valve disease using patient-specific three-dimensional calcification scans. Med Biol Eng Comput 2016;54:1683-94. Crossref

6. Spühler JH, Jansson J, Jansson N, Hoffman J. 3D fluid-structure interaction simulation of aortic valves using a unified continuum ALE FEM model. Front Physiol 2018;9:363. Crossref

7. Capelli C, Corsini C, Biscarini D, et al. Pledget-armed sutures affect the haemodynamic performance of biologic aortic valve substitutes: a preliminary experi- 
mental and computational study. Cardiovasc Eng Technol 2017;8:17-29. Crossref

8. Ghanbari H, de Mel A, Seifalian AM. Cardiovascular application of polyhedral oligomeric silsesquioxane nanomaterials: a glimpse into prospective horizons. Int J Nanomedicine 2011;6:775-86. $\underline{\text { Crossref }}$

9. Sanders B, Loerakker S, Fioretta ES, et al. Improved geometry of decellularized tissue engineered heart valves to prevent leaflet retraction. Ann Biomed Eng 2016;44:1061-71. Crossref

10. Marom G, Chiu WC, Crosby JR, et al. Numerical model of full-cardiac cycle hemodynamics in a total artificial heart and the effect of its size on platelet activation. J Cardiovasc Transl Res 2014;7:788-96. Crossref

11. Pibarot P, Dumesnil JG. Prosthetic heart valves: selection of the optimal prosthesis and long-term management. Circulation 2009;119:1034-48. $\underline{\text { Crossref }}$

12. Kytö V, Myllykangas ME, Sipilä J, Niiranen TJ, Rautava P, Gunn J. Long-term outcomes of mechanical vs biologic aortic valve prosthesis in patients older than 70 years. Ann Thorac Surg 2019;108:1354-60. Crossref

13. Witkowski A, Jastrzebski J, Dabrowski M, Chmielak Z. Second transcatheter aortic valve implantation for treatment of suboptimal function of previously implanted prosthesis: review of the literature. J Interv Cardiol 2014;27:300-7. Crossref

14. Saji M, Tobaru T, Higuchi R, Takanashi S, Takayama M, Isobe M. Repeat transcatheter aortic valve replacement using a $23 \mathrm{~mm}$ Evolut $\mathrm{R}$ in a small patient with a failed $20 \mathrm{~mm}$ SAPIEN XT. Cardiovasc Interv Ther 2019;34:80-2. $\underline{\text { Crossref }}$

15. Bilkhu R, Borger MA, Briffa NP, Jahangiri M. Sutureless aortic valve prostheses. Heart 2019;105:s16-20. $\underline{\text { Crossref }}$

16. Rotman OM, Bianchi M, Ghosh RP, Kovarovic B, Bluestein D. Principles of TAVR valve design, modelling, and testing. Expert Rev Med Devices 2018;15: 771-91. $\underline{\text { Crossref }}$

17. Li RL, Russ J, Paschalides C, et al. Mechanical considerations for polymeric heart valve development: biomechanics, materials, design and manufacturing. Biomaterials 2019;225:119493. Crossref

18. Kheradvar A, Groves EM, Dasi LP, et al. Emerging trends in heart valve engineering: part 1. Solutions for future. Ann Biomed Eng 2015;43:833-43.

19. Bezuidenhout D, Williams DF, Zilla P. Polymeric heart valves for surgical implantation, catheter-based technologies and heart assist devices. Biomaterials 2015;36:6-25. $\underline{\text { Crossref }}$
20. Rotman OM, Kovarovic B, Chiu WC, et al. Novel polymeric valve for transcatheter aortic valve replacement applications: in vitro hemodynamic study. Ann Biomed Eng 2019;47:113-25. $\underline{\text { Crossref }}$

21. Ghosh RP, Marom G, Rotman OM, et al. Comparative fluid-structure interaction analysis of polymeric transcatheter and surgical aortic valves' hemodynamics and structural mechanics. J Biomech Eng 2018 Jun 25. [Epub ahead of print] Crossref

22. Piatti F, Sturla F, Marom G, et al. Hemodynamic and thrombogenic analysis of a trileaflet polymeric valve using a fluid-structure interaction approach. J Biomech 2015;48:3641-9. $\underline{\text { Crossref }}$

23. Blum KM, Drews JD, Breuer CK. Tissue-engineered heart valves: a call for mechanistic studies. Tissue Eng Part B Rev 2018;24:240-53. $\underline{\text { Crossref }}$

24. Zhang BL, Bianco RW, Schoen FJ. Preclinical assessment of cardiac valve substitutes: current status and considerations for engineered tissue heart valves. Front Cardiovasc Med 2019;6:72. $\underline{\text { Crossref }}$

25. Cao C, Ang SC, Indraratna P, et al. Systematic review and meta-analysis of transcatheter aortic valve implantation versus surgical aortic valve replacement for severe aortic stenosis. Ann Cardiothorac Surg 2013;2:10-23. $\underline{\text { Crossref }}$

26. Jones BM, Krishnaswamy A, Tuzcu EM, et al. Matching patients with the ever-expanding range of TAVI devices. Nat Rev Cardiol 2017;14:615-26. Crossref

27. Seigerman ME, Nathan A, Anwaruddin S. The lotus valve system: an in-depth review of the technology. Curr Cardiol Rep 2019;21:157. Crossref

28. Wu C, Vasseur B, Maisel W. The march of transcatheter aortic valve replacement therapy-US Food and Drug Administration perspectives on device approval for patients at low surgical risk. JAMA Cardiol 2020;5:5-6. $\underline{\text { Crossref }}$

29. Durko AP, Osnabrugge RL, Van Mieghem NM, et al. Annual number of candidates for transcatheter aortic valve implantation per country: current estimates and future projections. Eur Heart J 2018;39:263542. $\underline{\text { Crossref }}$

30. Saxon JT, Allen KB, Cohen DJ, Chhatriwalla AK. Bioprosthetic valve fracture during valve-in-valve TAVR: bench to bedside. Interv Cardiol 2018;13:206. $\underline{\text { Crossref }}$

31. Dasi LP, Hatoum H, Kheradvar A, et al. On the mechanics of transcatheter aortic valve replacement. Ann Biomed Eng 2017;45:310-31. $\underline{\text { Crossref }}$

32. Makkar RR, Yoon SH, Leon MB, et al. Association between transcatheter aortic valve replacement for bicuspid vs tricuspid aortic stenosis and mortality or stroke. JAMA 2019;321:2193-202. Crossref 
33. Di Martino LF, Vletter WB, Ren B, et al. Prediction of paravalvular leakage after transcatheter aortic valve implantation. Int $\mathrm{J}$ Cardiovasc Imaging 2015;31: 1461-8. $\underline{\text { Crossref }}$

34. Sordelli C, Severino S, Ascione L, Coppolino P, Caso P. Echocardiographic assessment of heart valve prostheses. J Cardiovasc Echogr 2014;24:103-13. Crossref

35. Durko AP, Osnabrugge RL, Kappetein AP. Long-term outlook for transcatheter aortic valve replacement. Trends Cardiovasc Med 2018;28:174-83. $\underline{\text { Crossref }}$

36. Einav S, Bluestein D, Rotman OM. Special issue on "biofluid mechanics of multitude pathways: from cellular to organ”. J Biomech 2017;50:1-2. Crossref

37. de Jaegere P, De Santis G, Rodriguez-Olivares R, et al. Patient-specific computer modeling to predict aortic regurgitation after transcatheter aortic valve replacement. JACC Cardiovasc Interv 2016;9:50812. $\underline{\text { Crossref }}$

38. Fuchs A, Kofoed KF, Yoon SH, et al. Commissural alignment of bioprosthetic aortic valve and native aortic valve following surgical and transcatheter aortic valve replacement and its impact on valvular function and coronary filling. JACC Cardiovasc Interv 2018;11:1733-43. $\underline{\text { Crossref }}$

39. Mao W, Wang Q, Kodali S, Sun W. Numerical parametric study of paravalvular leak following a transcatheter aortic valve deployment into a patientspecific aortic root. J Biomech Eng 2018;140: 101007-11. $\underline{\text { Crossref }}$

40. Bianchi M, Marom G, Ghosh RP, et al. Patientspecific simulation of transcatheter aortic valve replacement: impact of deployment options on paravalvular leakage. Biomech Model Mechanobiol 2019; 18:435-51. $\underline{\text { Crossref }}$

41. Lavon K, Marom G, Bianchi M, et al. Biomechanical modeling of transcatheter aortic valve replacement in a stenotic bicuspid aortic valve: deployments and paravalvular leakage. Med Biol Eng Comput 2019;57: 2129-43. $\underline{\text { Crossref }}$

42. Luraghi G, Migliavacca F, Garcia-Gonzalez A, et al. On the modeling of patient-specific transcatheter aortic valve replacement: a fluid-structure interaction approach. Cardiovasc Eng Technol 2019;10:437-55. Crossref

43. Lowe GD. Virchow's triad revisited: abnormal flow. Pathophysiol Haemost Thromb 2003;33:455-7. Crossref

44. Kumar DR, Hanlin E, Glurich I, Mazza JJ, Yale SH. Virchow's contribution to the understanding of thrombosis and cellular biology. Clin Med Res 2010; 8:168-72. $\underline{\text { Crossref }}$
45. Wootton DM, Ku DN. Fluid mechanics of vascular systems, diseases, and thrombosis. Annu Rev Biomed Eng 1999;1:299-329. Crossref

46. Marom G, Bluestein D. Lagrangian methods for blood damage estimation in cardiovascular devices--How numerical implementation affects the results. Expert Rev Med Devices 2016;13:113-22. Crossref

47. Scotten LN, Siegel R. Thrombogenic potential of transcatheter aortic valve implantation with trivial paravalvular leakage. Ann Transl Med 2014;2:43. $\underline{\text { Crossref }}$

48. Nakatani S. Subclinical leaflet thrombosis after transcatheter aortic valve implantation. Heart 2017;103: 1942-6. Crossref

49. Rosseel L, De Backer O, Sondergaard L. Clinical valve thrombosis and subclinical leaflet thrombosis following transcatheter aortic valve replacement: is there a need for a patient-tailored antithrombotic therapy? Front Cardiovasc Med 2019;6:44. Crossref

50. Ducci A, Pirisi F, Tzamtzis S, Burriesci G. Transcatheter aortic valves produce unphysiological flows which may contribute to thromboembolic events: an in-vitro study. J Biomech 2016;49:4080-9. Crossref

51. Midha PA, Raghav V, Sharma R, et al. The fluid mechanics of transcatheter heart valve leaflet thrombosis in the neosinus. Circulation 2017;136:1598609. $\underline{\text { Crossref }}$

52. Chakravarty T, Sondergaard L, Friedman J, et al. Subclinical leaflet thrombosis in surgical and transcatheter bioprosthetic aortic valves: an observational study. Lancet 2017;389:2383-92. $\underline{\text { Crossref }}$

53. Makkar RR, Fontana G, Jilaihawi H, et al. Possible subclinical leaflet thrombosis in bioprosthetic aortic valves. N Engl J Med 2015;373:2015-24. Crossref

54. Jose J, Sulimov DS, El-Mawardy M, et al. Clinical bioprosthetic heart valve thrombosis after transcatheter aortic valve replacement: incidence, characteristics, and treatment outcomes. JACC Cardiovasc Interv 2017;10:686-97. $\underline{\text { Crossref }}$

55. Hatoum H, Moore BL, Maureira P, Dollery J, Crestanello JA, Dasi LP. Aortic sinus flow stasis likely in valve-in-valve transcatheter aortic valve implantation. J Thorac Cardiovasc Surg 2017;154:32-43 e1. Crossref

56. Vahidkhah K, Javani S, Abbasi M, et al. Blood stasis on transcatheter valve leaflets and implications for valve-in-valve leaflet thrombosis. Ann Thorac Surg 2017;104:751-9. $\underline{\text { Crossref }}$

57. Vahidkhah K, Barakat M, Abbasi M, et al. Valve thrombosis following transcatheter aortic valve replacement: significance of blood stasis on the leaflets. Eur J Cardiothorac Surg 2017;51:927-35. $\underline{\text { Crossref }}$ 
58. Vahidkhah K, Azadani AN. Supra-annular valve-invalve implantation reduces blood stasis on the transcatheter aortic valve leaflets. J Biomech 2017;58:11422. $\underline{\text { Crossref }}$

59. Khan JM, Dvir D, Greenbaum AB, et al. Transcatheter laceration of aortic leaflets to prevent coronary obstruction during transcatheter aortic valve replacement: concept to first-in-human. JACC Cardiovasc Interv 2018;11:677-89. $\underline{\text { Crossref }}$

6o. Hatoum H, Maureira P, Lilly S, Dasi LP. Leaflet laceration to improve neosinus and sinus flow after valvein-valve. Circ Cardiovasc Interv 2019;12:e007739. Crossref

61. Khodaee F, Qiu D, Dvir D, Azadani AN. Reducing the risk of leaflet thrombosis in transcatheter aortic valvein-valve implantation by BASILICA: a computational simulation study. EuroIntervention 2019;15:67-70. Crossref

62. Mosquera VX, Gonzalez-Barbeito M, BouzasMosquera A, et al. Efficacy and safety of transcatheter valve-in-valve replacement for Mitroflow bioprosthetic valve dysfunction. J Card Surg 2018;33:35662. $\underline{\text { Crossref }}$

63. Cheung AW, Ye J, Dvir D, Wood DA, Webb JG. Aortic valve-in-valve in externally mounted bioprosthesis: a safe treatment option for bioprosthetic structural valve dysfunction. Innovations (Phila) 2018;13:171-6. Crossref

64. Spaziano M, Akodad M, Hovasse T, Lefevre T, Bouvier E, Chevalier B. Simultaneous TAVR and left main "chimney" stenting in a patient with low left main height. JACC Cardiovasc Interv 2017;10:e1857. $\underline{\text { Crossref }}$

65. Heitkemper M, Hatoum H, Azimian A, et al. Modeling risk of coronary obstruction during transcatheter aortic valve replacement. J Thorac Cardiovasc Surg 2020;159:829-38.e3. Crossref

66. Wald S, Liberzon A, Avrahami I. A numerical study of the hemodynamic effect of the aortic valve on coronary flow. Biomech Model Mechanobiol 2018;17: 319-38. $\underline{\text { Crossref }}$

67. Larion S, Moore JR, Ammar C, Panneton JM. TEVAR rescue of an embolized Edwards Sapien XT valve following TAVR. J Endovasc Ther 2015;22:819-23. Crossref

68. Yaakobovich H, Plitman Mayo R, Zaretsky U, Finkelstein A, Marom G. Numerical models of valve-invalve implantation: effect of intentional leaflet laceration on the anchorage. Biomech Model Mechanobiol 2020;19:415-26. $\underline{\text { Crossref }}$

69. Cosentino F, Scardulla F, D'Acquisto L, et al. Computational modeling of bicuspid aortopathy: towards personalized risk strategies. J Mol Cell Cardiol 2019;131:122-31. Crossref

70. Schultz C, Rodriguez-Olivares R, Bosmans J, et al. Patient-specific image-based computer simulation for the prediction of valve morphology and calcium displacement after TAVI with the Medtronic Corevalve and the Edwards Sapien valve. EuroIntervention 2016;11:1044-52. Crossref

71. Brouwer J, Gheorghe L, Nijenhuis VJ, et al. Insight on patient specific computer modeling of transcatheter aortic valve implantation in patients with bicuspid aortic valve disease. Catheter Cardiovasc Interv 2019;93:1097-105. $\underline{\text { Crossref }}$

72. Dowling C, Bavo AM, El Faquir N, et al. Patientspecific computer simulation of transcatheter aortic valve replacement in bicuspid aortic valve morphology. Circ Cardiovasc Imaging 2019;12:e009178. Crossref

73. Dowling C, Firoozi S, Brecker SJ. First-in-human experience with patient-specific computer simulation of TAVR in bicuspid aortic valve morphology. JACC Cardiovasc Interv 2020;13:184-92. $\underline{\text { Crossref }}$

74. Karady J, Ntalas I, Prendergast B, et al. Transcatheter mitral valve replacement in mitral annulus calcification - "The art of computer simulation". J Cardiovasc Comput Tomogr 2018;12:153-7. $\underline{\text { Crossref }}$

75. Serban R, Redwood S, Prendergast B, Rajani R. Realtime image integration for transcatheter mitral valve replacement in mitral annular calcification. J Thorac Cardiovasc Surg 2019;157:e135-9. $\underline{\text { Crossref }}$

76. Adams HSL, Rajani R, Hildick-Smith D, Redwood S. "Between a rock and the mitral valve space": transcatheter mitral valve-in-valve implantation for paravalvular leak and refractory hemolysis complicated by circumflex coronary occlusion. Catheter Cardiovasc Interv 2019 Nov 6. [Epub ahead of print] Crossref

77. Rocatello G, El Faquir N, de Backer O, et al. The impact of size and position of a mechanical expandable transcatheter aortic valve: novel insights through computational modelling and simulation. J Cardiovasc Transl Res 2019;12:435-46. Crossref

78. Rocatello G, De Santis G, De Bock S, De Beule M, Segers P, Mortier P. Optimization of a transcatheter heart valve frame using patient-specific computer simulation. Cardiovasc Eng Technol 2019;10:456-68. $\underline{\text { Crossref }}$

79. Rocatello G, El Faquir N, De Santis G, et al. Patientspecific computer simulation to elucidate the role of contact pressure in the development of new conduction abnormalities after catheter-based implantation of a self-expanding aortic valve. Circ Cardiovasc Interv 2018;11:e005344. $\underline{\text { Crossref }}$ 
80. El Faquir N, Ren B, Van Mieghem NM, Bosmans J, de Jaegere PP. Patient-specific computer modelling its role in the planning of transcatheter aortic valve implantation. Neth Heart J 2017;25:100-5. $\underline{\text { Crossref }}$

81. Benjamin EJ, Muntner P, Alonso A, et al. Heart disease and stroke statistics-2019 update: a report from the American Heart Association. Circulation 2019;139:e56-528. Crossref

82. Enriquez-Sarano M, Akins CW, Vahanian A. Mitral regurgitation. Lancet 2009;373:1382-94. Crossref

83. Asgar AW, Mack MJ, Stone GW. Secondary mitral regurgitation in heart failure: pathophysiology, prognosis, and therapeutic considerations. J Am Coll Cardiol 2015;65:1231-48. $\underline{\text { Crossref }}$

84. Feldman T, Kar S, Rinaldi M, et al. Percutaneous mitral repair with the MitraClip system: safety and midterm durability in the initial EVEREST (endovascular valve edge-to-edge repair study) cohort. J Am Coll Cardiol 2009;54:686-94. $\underline{\text { Crossref }}$

85. Saaid H, Segers P, Novara M, Claessens T, Verdonck P. Single calibration multiplane stereo-PIV: the effect of mitral valve orientation on three-dimensional flow in a left ventricle model. Exp Fluids 2018;59:49. Crossref

86. Lamelas J, Aberle CM, Gnanashanmugam S. Innovative Approaches to Mitral Valve Repair and Replacement. In: Carabello BA, ed. Valvular Heart Disease. London: Springer London; 2020:131-76.

87. Magne J, Girerd N, Senechal M, et al. Mitral repair versus replacement for ischemic mitral regurgitation: comparison of short-term and long-term survival. Circulation 2009;120:S104-11. $\underline{\text { Crossref }}$

88. Jouan J, Berrebi A, Chauvaud S, Menasche P, Carpentier A, Fabiani JN. Mitral valve reconstruction in Barlow disease: long-term echographic results and implications for surgical management. $J$ Thorac Cardiovasc Surg 2012;143:S17-20. $\underline{\text { Crossref }}$

89. Rausch MK, Zollner AM, Genet M, Baillargeon B, Bothe W, Kuhl E. A virtual sizing tool for mitral valve annuloplasty. Int $\mathrm{J}$ Numer Method Biomed Eng 2017;33:e02788. $\underline{\text { Crossref }}$

90. Lindman BR, Melby SJ, Quader N, Sintek MA, Moon MR. Comprehensive Assessment of Primary Mitral Valve Disease: Clinical Presentation, Diagnosis, Medical and Surgical Therapy. In: Carabello BA, ed. Valvular Heart Disease. London: Springer London; 2020:103-24.

91. Bridgewater B, Hooper T, Munsch C, et al. Mitral repair best practice: proposed standards. Heart 2006;92:939-44. Crossref

92. Vassileva CM, Boley T, Markwell S, Hazelrigg S. Meta-analysis of short-term and long-term survival following repair versus replacement for ischemic mitral regurgitation. Eur J Cardiothorac Surg 2011; 39:295-303. $\underline{\text { Crossref }}$

93. Muller DWM, Farivar RS, Jansz P, et al. Transcatheter mitral valve replacement for patients with symptomatic mitral regurgitation: a global feasibility trial. J Am Coll Cardiol 2017;69:381-91. $\underline{\text { Crossref }}$

94. Mirabel M, Iung B, Baron G, et al. What are the characteristics of patients with severe, symptomatic, mitral regurgitation who are denied surgery? Eur Heart J 2007;28:1358-65. $\underline{\text { Crossref }}$

95. Kheradvar A, Groves EM, Simmons CA, et al. Emerging trends in heart valve engineering: part III. Novel technologies for mitral valve repair and replacement. Ann Biomed Eng 2015;43:858-70. $\underline{\text { Crossref }}$

96. Nishimura RA, Otto CM, Bonow RO, et al. 2014 AHA/ACC guideline for the management of patients with valvular heart disease: a report of the American College of Cardiology/American Heart Association task force on practice guidelines. Circulation 2014; 129:e521-643. $\underline{\text { Crossref }}$

97. Praz F, Spargias K, Chrissoheris M, et al. Compassionate use of the pascal transcatheter mitral valve repair system for patients with severe mitral regurgitation: a multicentre, prospective, observational, firstin-man study. Lancet 2017;390:773-80. Crossref

98. Maisano F, Taramasso M, Nickenig G, et al. Cardioband, a transcatheter surgical-like direct mitral valve annuloplasty system: early results of the feasibility trial. Eur Heart J 2016;37:817-25. Crossref

99. Testa L, Latib A, Montone RA, Bedogni F. Transcatheter mitral valve regurgitation treatment: state of the art and a glimpse to the future. $J$ Thorac Cardiovasc Surg 2016;152:319-27. Crossref

100. Regueiro A, Granada JF, Dagenais F, Rodes-Cabau J. Transcatheter mitral valve replacement: insights from early clinical experience and future challenges. $J$ Am Coll Cardiol 2017;69:2175-92. Crossref

101. Preston-Maher GL, Torii R, Burriesci G. A technical review of minimally invasive mitral valve replacements. Cardiovasc Eng Technol 2015;6:174-84. Crossref

102. Khan JM, Rogers T, Babaliaros VC, Fusari M, Greenbaum AB, Lederman RJ. Predicting left ventricular outflow tract obstruction despite anterior mitral leaflet resection: the "Skirt NeoLVOT". JACC Cardiovasc Imaging 2018;11:1356-9. $\underline{\text { Crossref }}$

103. Babaliaros VC, Greenbaum AB, Khan JM, et al. Intentional percutaneous laceration of the anterior mitral leaflet to prevent outflow obstruction during transcatheter mitral valve replacement: first-in-human experience. JACC Cardiovasc Interv 2017;10:798809. $\underline{\text { Crossref }}$ 
104. Connell PS, Azimuddin AF, Kim SE, et al. Regurgitation hemodynamics alone cause mitral valve remodeling characteristic of clinical disease states in vitro. Ann Biomed Eng 2016;44:954-67. Crossref

105. Sturla F, Vismara R, Jaworek M, et al. In vitro and in silico approaches to quantify the effects of the Mitraclip $\AA$ system on mitral valve function. $\mathrm{J}$ Biomech 2017;50:83-92. Crossref

106. Vismara R, Leopaldi AM, Piola M, et al. In vitro assessment of mitral valve function in cyclically pressurized porcine hearts. Med Eng Phys 2016; 38:346-53.

107. Kunzelman KS, Cochran RP, Chuong C, Ring WS, Verrier ED, Eberhart RD. Finite element analysis of the mitral valve. J Heart Valve Dis 1993;2:326-40.

108. Dahl SK, Vierendeels J, Degroote J, Annerel S, Hellevik LR, Skallerud B. FSI simulation of asymmetric mitral valve dynamics during diastolic filling. Comput Methods Biomech Biomed Engin 2012;15: 121-30. $\underline{\text { Crossref }}$

109. Chandran KB, Kim H. Computational mitral valve evaluation and potential clinical applications. Ann Biomed Eng 2015;43:1348-62. Crossref

110. Pham T, Kong F, Martin C, et al. Finite element analysis of patient-specific mitral valve with mitral regurgitation. Cardiovasc Eng Technol 2017;8:3-16. $\underline{\text { Crossref }}$

111. Toma M, Einstein DR, Bloodworth $\mathrm{CH}$ 4th, Cochran RP, Yoganathan AP, Kunzelman KS. Fluid-structure interaction and structural analyses using a comprehensive mitral valve model with $3 \mathrm{D}$ chordal structure. Int J Numer Method Biomed Eng 2017;33:e2815. Crossref

112. Mao W, Caballero A, McKay R, Primiano C, Sun W. Fully-coupled fluid-structure interaction simulation of the aortic and mitral valves in a realistic $3 \mathrm{D}$ left ventricle model. PLoS One 2017;12:e0184729.

113. Kunzelman KS, Reimink MS, Cochran RP. Flexible versus rigid ring annuloplasty for mitral valve annular dilatation: a finite element model. J Heart Valve Dis 1998;7:108-16.

114. Maisano F, Redaelli A, Soncini M, Votta E, Arcobasso L, Alfieri O. An annular prosthesis for the treatment of functional mitral regurgitation: finite element model analysis of a dog bone-shaped ring prosthesis. Ann Thorac Surg 2005;79:1268-75. $\underline{\text { Crossref }}$

115. Votta E, Maisano F, Bolling SF, Alfieri O, Montevecchi FM, Redaelli A. The geoform diseasespecific annuloplasty system: a finite element study. Ann Thorac Surg 2007;84:92-101. Crossref

116. Wong VM, Wenk JF, Zhang Z, et al. The effect of mitral annuloplasty shape in ischemic mitral regurgi- tation: a finite element simulation. Ann Thorac Surg 2012;93:776-82. $\underline{\text { Crossref }}$

117. Stevanella M, Maffessanti F, Conti CA, et al. Mitral valve patient-specific finite element modeling from cardiac MRI: application to an annuloplasty procedure. Cardiovasc Eng Technol 2011;2:66-76. $\underline{\text { Crossref }}$

118. Choi A, Rim Y, Mun JS, Kim H. A novel finite element-based patient-specific mitral valve repair: virtual ring annuloplasty. Biomed Mater Eng 2014; 24:341-7. $\underline{\text { Crossref }}$

119. Mansi T, Voigt I, Georgescu B, et al. An integrated framework for finite-element modeling of mitral valve biomechanics from medical images: application to MitralClip intervention planning. Med Image Anal 2012;16:1330-46. $\underline{\text { Crossref }}$

120. Morgan AE, Wozniak CJ, Gulati S, et al. Association of uneven MitraClip application and leaflet stress in a finite element model. JAMA Surg 2017;152:111-14. Crossref

121. Sturla F, Redaelli A, Puppini G, Onorati F, Faggian G, Votta E. Functional and biomechanical effects of the edge-to-edge repair in the setting of mitral regurgitation: consolidated knowledge and novel tools to gain insight into its percutaneous implementation. Cardiovasc Eng Technol 2015;6:117-40. Crossref

122. Kamakoti R, Dabiri Y, Wang DD, Guccione J, Kassab GS. Numerical simulations of MitraClip placement: clinical implications. Sci Rep 2019;9:15823. Crossref

123. Lee FA. Hemodynamics of the right ventricle in normal and disease states. Cardiol Clin 1992;10:5967. Crossref

124. Fathallah M, Krasuski RA. Pulmonic valve disease: review of pathology and current treatment options. Curr Cardiol Rep 2017;19:108. Crossref

125. Chatterjee A, Bajaj NS, McMahon WS, et al. Transcatheter pulmonary valve implantation: a comprehensive systematic review and meta-analyses of observational studies. J Am Heart Assoc 2017;6: eoo6432. $\underline{\text { Crossref }}$

126. Malekzadeh-Milani S, Ladouceur M, Cohen S, Iserin L, Boudjemline Y. Results of transcatheter pulmonary valvulation in native or patched right ventricular outflow tracts. Arch Cardiovasc Dis 2014;107:592-8. Crossref

127. Meadows JJ, Moore PM, Berman DP, et al. Use and performance of the Melody transcatheter pulmonary valve in native and postsurgical, nonconduit right ventricular outflow tracts. Circ Cardiovasc Interv 2014;7:374-80. Crossref

128. Faccini A, Butera G. Tricuspid regurgitation as a complication of Edwards Sapien XT valve implantation in pulmonary position a problem to deal with. Catheter Cardiovasc Interv 2018;91:927-31. 
129. Suzuki I, Shiraishi Y, Yabe S, et al. Engineering analysis of the effects of bulging sinuses in a newly designed pediatric pulmonary heart valve on hemodynamic function. J Artif Organs 2012;15:49-56. Crossref

130. Capelli C, Sauvage E, Giusti G, et al. Patient-specific simulations for planning treatment in congenital heart disease. Interface Focus 2018;8:20170021. Crossref

131. Li CL, Baird C, Yao J, et al. Computational modeling of human bicuspid pulmonary valve dynamic deformation in patients with tetralogy of fallot. Comput Model Eng Sci 2019;119:227-44. Crossref

132. Taramasso M, Pozzoli A, Guidotti A, et al. Percutaneous tricuspid valve therapies: the new frontier. Eur Heart J 2017;38:639-47. $\underline{\text { Crossref }}$

133. Schofer J, Bijuklic K, Tiburtius C, Hansen L, Groothuis A, Hahn RT. First-in-human transcatheter tricuspid valve repair in a patient with severely regurgitant tricuspid valve. J Am Coll Cardiol 2015;65:1190-5. Crossref

134. Latib A, Agricola E, Pozzoli A, et al. First-in-man implantation of a tricuspid annular remodeling device for functional tricuspid regurgitation. JACC Cardiovasc Interv 2015;8:e211-14. Crossref

135. Rogers T, Ratnayaka K, Sonmez M, et al. Transatrial intrapericardial tricuspid annuloplasty. JACC Cardiovasc Interv 2015;8:483-91. Crossref

136. Lapenna E, De Bonis M, Verzini A, et al. The clover technique for the treatment of complex tricuspid valve insufficiency: midterm clinical and echocardiographic results in 66 patients. Eur J Cardiothorac Surg 2010;37:1297-303. $\underline{\text { Crossref }}$

137. Vismara R, Gelpi G, Prabhu S, et al. Transcatheter edge-to-edge treatment of functional tricuspid regurgitation in an ex vivo pulsatile heart model. $\mathrm{J}$ Am Coll Cardiol 2016;68:1024-33. $\underline{\text { Crossref }}$

138. Dabiri Y, Yao J, Sack KL, Kassab GS, Guccione JM. Tricuspid valve regurgitation decreases after MitraClip implantation: fluid structure interaction simulation. Mech Res Commun 2019;97:96-100. Crossref

139. Kalejs M, von Segesser LK. Rapid prototyping of compliant human aortic roots for assessment of valved stents. Interact Cardiovasc Thorac Surg 2009; 8:182-6. $\underline{\text { Crossref }}$

140. Maragiannis D, Jackson MS, Igo SR, et al. Replicating patient-specific severe aortic valve stenosis with functional $3 \mathrm{D}$ modeling. Circ Cardiovasc Imaging 2015;8:e003626. $\underline{\text { Crossref }}$

141. Mummert J, Sirois E, Sun W. Quantification of biomechanical interaction of transcatheter aortic valve stent deployed in porcine and ovine hearts. Ann Biomed Eng 2013;41:577-86. Crossref

142. Qian Z, Wang K, Liu S, et al. Quantitative prediction of paravalvular leak in transcatheter aortic valve replacement based on tissue-mimicking $3 \mathrm{D}$ printing. JACC Cardiovasc Imaging 2017;10:719-31. Crossref

143. Ripley B, Kelil T, Cheezum MK, et al. 3D printing based on cardiac CT assists anatomic visualization prior to transcatheter aortic valve replacement. J Cardiovasc Comput Tomogr 2016;10:28-36. Crossref

144. Rotman OM, Kovarovic B, Sadasivan C, Gruberg L, Lieber BB, Bluestein D. Realistic vascular replicator for TAVR procedures. Cardiovasc Eng Technol 2018;9:339-50. Crossref

145. Tanaka Y, Saito S, Sasuga S, et al. Quantitative assessment of paravalvular leakage after transcatheter aortic valve replacement using a patientspecific pulsatile flow model. Int J Cardiol 2018;258: 313-20. Crossref

146. Hatoum H, Dollery J, Lilly SM, Crestanello J, Dasi LP. Impact of patient-specific morphologies on sinus flow stasis in transcatheter aortic valve replacement: an in vitro study. J Thorac Cardiovasc Surg 2019; 157:540-9. $\underline{\text { Crossref }}$

147. Vukicevic M, Mosadegh B, Min JK, Little SH. Cardiac $3 \mathrm{D}$ printing and its future directions. JACC Cardiovasc Imaging 2017;10:171-84. Crossref

148. Vukicevic M, Vekilov DP, Grande-Allen JK, Little SH. Patient-specific $3 \mathrm{D}$ valve modeling for structural intervention. Struct Heart 2017;1:236-48. Crossref

149. Morrison TM, Pathmanathan P, Adwan M, Margerrison $\mathrm{E}$. Advancing regulatory science with computational modeling for medical devices at the FDA's office of science and engineering laboratories. Front Med (Lausanne) 2018;5:241. $\underline{\text { Crossref }}$

150. Chiu WC, Alemu Y, McLarty AJ, Einav S, Slepian MJ, Bluestein D. Ventricular assist device implantation configurations impact overall mechanical circulatory support system thrombogenic potential. ASAIO J 2017;63:285-92. $\underline{\text { Crossref }}$ 